\title{
INDUCTION OF A GEOCHEMICAL BARRIER FOR As, Fe AND S IMMOBILIZATION IN A SULFIDE SUBSTRATE(1)
}

\author{
Igor Rodrigues de Assis (2), Luiz Eduardo Dias(2), Emerson Silva Ribeiro \\ Jr. ${ }^{(3)}$, Walter Antônio Pereira Abrahão(2), Jaime Wilson Vargas de \\ Mello(2) $^{(2)}$ Renato Welmer Veloso ${ }^{(4)}$
}

\begin{abstract}
SUMMARY
Acid mine drainage (AMD) is an environmental concern due to the risk of element mobilization, including toxic elements, and inclusion in the food chain. In this study, three cover layers were tested to minimize $\mathrm{As}, \mathrm{Fe}$ and $\mathrm{S}$ mobilization from a substrate from former gold mining, containing pyrite and arsenopyrite. For this purpose, different layers (capillary break, sealant and cover layer) above the substrate and the induction of a geochemical barrier (GB) were used to provide suitable conditions for adsorption and co-precipitation of the mobilized As. Thirteen treatments were established to evaluate the leaching of As, Fe and $\mathrm{S}$ from a substrate in lysimeters. The $\mathrm{pH}, \mathrm{As}, \mathrm{Fe}, \mathrm{S}, \mathrm{Na}$, and $\mathrm{K}$ concentrations and total volume of the leachates were determined. Mineralogical analyses were realized in the substrate at the end of the experimental period. Lowest amounts of $\mathrm{As}, \mathrm{Fe}$ and $\mathrm{S}$ (average values of 5.47, 48.59 and $132.89 \mathrm{~g} / \mathrm{lysimeter}$ ) were leached in the treatments that received $\mathrm{Na}$ and $\mathrm{K}$ to induce GB formation. Mineralogical analyses indicated jarosite formation in the control treatment and in treatments that received $\mathrm{Na}$ and $\mathrm{K}$ salts. However, the jarosite amounts in these treatments were higher than in the control, suggesting that these salts accelerated the GB formation. High amounts of As, Fe and S (average values of $11.7,103.94$ and $201.13 \mathrm{~g} / \mathrm{lysimeter}$ ) were observed in the leachate from treatments without capillary break layer. The formation of geochemical barrier and the use of different layers over the sulfide substrate proved to be efficient techniques to decrease $\mathrm{As}, \mathrm{Fe}$ and $\mathrm{S}$ mobilization and mitigate the impact of acid mine drainage.
\end{abstract}

Index-terms: jarosite, arsenic, cover layers, gold mining, rehabilitation.

(1) Part of MSc Dissertation of first author presented at the Soil Science Post-Graduation Program of Federal University of Viçosa, UFV. This work received financial support from Fapemig and INCT-Aqua (CNPq). Received for publication in July 29,2011 and approved in January 24, 2012.

(2) Professor, Soil Department, Federal University of Viçosa, UFV, CEP 36571-000 Viçosa (MG), Brazil. E-mails: igor.assis@ufv.br; ledias@ufv.br; wabrahao@ufv.br; jwvmello@ufv.br

(3) Analyst of The National Council for Scientific and Technological Development, CNPq, CEP 71605-001 Brasília (DF). E-mail: eribeiro@ cnpq.br

(4) Doctoral student of Pos-Graduate in Soils and Plant Nutrition. INCT-Aqua, CNPq scholarship, CEP $36570-000$ Viçosa (MG). E-mail: renatowv@gmail.com 


\title{
RESUMO: INDUÇÃO DE BARREIRA GEOQUÍMICA PARA IMOBILIZAÇÃO DE AS, FE E S EM UM SUBSTRATO SULFETADO
}

\begin{abstract}
A drenagem ácida de minas (DAM) é uma preocupação ambiental devido ao risco de mobilização de elementos, incluindo elementos tóxicos, e ingresso na cadeia alimentar. Neste estudo, três camadas de cobertura foram testadas para minimizar a mobilização de As, Fe e S em um substrato remanescente de mineração de ouro, contendo pirita e arsenopirita. Para isso, diferentes camadas (camada de quebra de capilaridade, selante e de cobertura) dispostas sobre o substrato e a indução de uma barreira geoquímica (BG) foram usadas a fim de propiciar condições adequadas para adsorção e coprecipitação do As mobilizado. Treze tratamentos foram estabelecidos para avaliar a lixiviação de As, Fe e S do substrato, em lisimetros. $O$ valor de $\mathrm{pH}$, as concentrações de As, $\mathrm{Fe}, \mathrm{S}, \mathrm{Na}$ e $\mathrm{K}$ e o volume total de lixiviado foram determinados. As análises mineralógicas foram realizadas com amostras do substrato no final do período experimental. As menores quantidades de As, Fe e S foram lixiviadas nos tratamentos que receberam Na e K para induzir a formação de BG, com valores médios de 5,47, 48,59 e 132,89 g/lisímetros, respectivamente. A análise mineralógica revelou a formação de jarosita no tratamento controle e nos tratamentos que receberam sais de $\mathrm{Na}$ e K. Entretanto, a quantidade de jarosita nestes tratamentos foi superior à encontrada no controle, indicando que esses sais aceleraram a formação da BG. Elevadas quantidades de As, Fe e S foram observadas nos lixiviados dos tratamentos sem camada de quebra de capilaridade, com valores médios de 11,7, 103,94 e 201,13 g/lisimetros, respectivamente. A formação da BG e o uso de diferentes camadas sobre o substrato sulfetado mostraram ser técnicas eficientes para diminuir a mobilização de As, Fe e S e mitigar os impactos da drenagem ácida de minas.
\end{abstract}

Termos de indexação: jarosita, arsênio, camadas de cobertura, mineração de ouro, reabilitação.

\section{INTRODUCTION}

One of the main environmental problems in the State of Minas Gerais, Brazil, is the pollution of surface and ground water by residual material from mining activities. These materials may contain sulfide minerals such as pyrite, which oxidizes in contact with water and air, producing acidic water. This problem is common in some mines, it is known as acid mine drainage (AMD), and affects rivers and groundwater by contamination with high levels of heavy metals ( $\mathrm{Pb}, \mathrm{Cd}, \mathrm{Ni}$, etc.) and metalloids (As, $\mathrm{B}$, etc.), which have disastrous effects on the entire food chain (Evangelou, 1995; Robinson, 2010).

Currently, the Brazilian regulation for environmental protection determines that the mining area must be recovered after the end of the exploration. In addition, special cares should be taken in areas with presence of metallic sulfides. Mitigating practices to isolate the sulfide material from water and air are important to avoid or reduce the formation of AMD. Once the process of AMD formation has started, procedures such as the use of geochemical barriers (GB) to minimize the mobilization of sulfide oxidation products and the use of lime materials to neutralize acidity must be considered.

The GB consists of a "layer" that acts as a barrier to the mobilization of soluble products of the AMD, which are toxic or harmful to the environment. This layer is formed by the products of sulfide oxidation such as iron sulfates and (hydr)oxides. The most common final products of AMD are jarosite $\left(\mathrm{RFe}_{3}\left(\mathrm{SO}_{4}\right)_{2}(\mathrm{OH})_{6}\right)$, where $\mathrm{R}$ is usually $\mathrm{K}, \mathrm{Na}, \mathrm{H}$ ions and/or $\mathrm{Pb}$; schwertmanite $\left(\mathrm{Fe}_{8} \mathrm{O}_{8}(\mathrm{OH})_{6} \mathrm{SO}_{4}\right)$, goethite $(\alpha-\mathrm{FeOOH})$, and ferrihydrite $\left(\mathrm{Fe}_{5} \mathrm{HO}_{8} \cdot 4 \mathrm{H}_{2} \mathrm{O}\right)$, although the identification of ferrihydrite and schwertmanite is difficult due to their occurrence in very small particles, smaller than $10 \mathrm{~nm}$ (Murad \& Rojik, 2004). Besides, the formation of jarosite and natrojarosite can be induced by the presence or addition of $\mathrm{Na}$ and $\mathrm{K}$ salts. The use of similar barriers for the same purpose was demonstrated by Desisto et al. (2011).

Therefore, the addition of $\mathrm{Na}$ and $\mathrm{K}$ to the system favors the GB formation. These minerals are formed and become more stable than iron oxides at low $\mathrm{pH}$ (approximately 2 - 4) when the oxidation-reduction potential (Eh) is sufficiently high (Fanning \& Fanning, 1989). Regardless of the immediately formed mineral phases, the products undergo transformations and generate goethite, which becomes more stable in the long term (Bigham et al., 1996; Singh et al., 1999; Gagliano et al., 2004; Schwertmann \& Carlson, 2005). Further information on the mineralogy of AMD precipitates has been published by the American Chemical Society (Alpers \& Blow, 1994) and the Mineralogical Association of Canada (Jambor et al., 2003). 
In addition to pyrite, there are other sulfide minerals such as chalcopyrite $\left(\mathrm{CuFeS}_{2}\right)$, tetrahedrite, $\left[(\mathrm{Cu}, \mathrm{Fe})_{12} \mathrm{Sb}_{4} \mathrm{~S}_{13}\right]$ tennantite $\left[(\mathrm{Cu}, \mathrm{Fe})_{12} \mathrm{As}_{4} \mathrm{~S}_{13}\right]$ and arsenopyrite (AsFeS), that is easily solubilized and can release toxic metals when oxidized. Among these minerals, arsenopyrite is noteworthy since its oxidation has caused serious problems for human and animal health around the world, e.g., in India, in the South of Bangladesh (Dave, 1996). Arsenic is currently the first in a list of the top 20 most hazardous substances to human health, according to the Agency for Toxic Substances and Disease Registry (ATSDR, 2011), and its mobility is independent of the total As in the solid phases (Huang et al., 2006).

When mines are shut down, incorrect or ineffective practices can result in a continuous AMD formation process, which can cause serious damage to human and animal health in the long term. The use of appropriate practices, however, can minimize the process and may even stop it. This study aimed to evaluate the effectiveness of some mitigation practices of AMD to minimize As, Fe and $\mathrm{S}$ mobilization of a sulfide substrate resulting from gold mining in Paracatu, MG, Brazil.

For this study, material from Paracatu was used in lysimeters or column experiments and these lysimeters were placed in a laboratory simulating the climatic conditions of Paractu.

\section{MATERIAL AND METHODS}

The laboratory experiment was performed using material from a former gold mine in Paracatu, State of Minas Gerais, Brazil, and lasted 24 months.

Lysimeters consisting of tempered glass $6.0 \mathrm{~mm}$ thickness, $20.0 \mathrm{~cm}$ wide section, depth $20.0 \mathrm{~cm}$, height $100.0 \mathrm{~cm}$ ) were prepared, with a sloping bottom to facilitate water drainage, and lined at the bottom with glass wool to prevent loss of solid particles in the leachate.

Thirteen different treatments consisting of combinations of cover, sealant and capillary break layers were considered. Those layers were mounted over lysimeters that were placed on a little weathered layer of the substrate (B2). Additional chemical treatments, such as $\mathrm{K}$ and $\mathrm{Na}$ salts to induce GB formation and a dispersant to reduce the permeability of the material were used in the capillary break layer. A brief description of these treatments is given in table 1 . The material structure in the lysimeters, from the bottom to the top, consisted of a sulfide substrate (B2), capillary break layer, sealant layer, and finally the cover layer. The control treatment (T1) contained only the B2 substrate, with no overlying layer. The
Table 1. Description of the experimental treatments with lysimeters

\begin{tabular}{|c|c|c|c|}
\hline \multirow{2}{*}{ Treatment } & \multicolumn{3}{|c|}{ Layer } \\
\hline & Cover & Sealant & $\begin{array}{c}\text { Capillary } \\
\text { break }\end{array}$ \\
\hline 1 & - & - & - \\
\hline 2 & Soil & Soil & - \\
\hline 3 & Soil & Soil & Sand $+\mathrm{SO}+\mathrm{GB}^{(1)}$ \\
\hline 4 & Soil & B1 substrate & Sand + SO ${ }^{(2)}$ \\
\hline 5 & B1 substrate & Soil & - \\
\hline 6 & B1 substrate & B1 substrate & - \\
\hline 7 & B1 substrate & B1 substrate & Sand \\
\hline 8 & B1 substrate & B1 substrate & Sand + GB \\
\hline 9 & B1 substrate & B1 substrate & Sand + SO + GB \\
\hline 10 & Soil + B1 & Laterite & Limestone \\
\hline 11 & Soil + B1 & Laterite & Sand + SO \\
\hline 12 & Soil + B1 & B1 substrate & Limestone \\
\hline 13 & Soil + B1 & B1 substrate & Sand + SO \\
\hline
\end{tabular}

(1) Geochemical Barrier. ${ }^{(2)}$ Sodium Oxalate.

experiment was arranged in randomized blocks, in an incomplete factorial design, with three replications.

The lysimeters were equipped in the sequence: first, a layer of substrate B2 $(30 \mathrm{~kg}$ material, height $\sim 50 \mathrm{~cm}$ ) was added to all lysimeters. Then, the capillarity break layer (height $\sim 5 \mathrm{~cm}$ ) of sand $(2 \mathrm{~kg}$ per lysimeter) or limestone (diameter $\mid<1 \mathrm{~cm}$ and $4 \mathrm{~kg} / \mathrm{ysimeter}$ ) was laid over the substrate. Additionally in this layer, $\mathrm{Na}$ oxalate $\left(2 \mathrm{~g} \mathrm{~kg}^{-1}\right)$ and/ or $\mathrm{NaCl}+\mathrm{KCl}(\mathrm{Na}+\mathrm{K}=2 \%(\mathrm{w} / \mathrm{w}))$ was added to some of the treatments. Immediately above this layer, the cover layer was stacked, consisting of $30 \mathrm{~kg}$ soil or $40 \mathrm{~kg}$ rather weathered substrate (B1), or even $15 \mathrm{~kg}$ soil or laterite and $20 \mathrm{~kg}$ substrate B1, forming a layer with a height of approximately $20 \mathrm{~cm}$. Finally, $20 \mathrm{~kg}$ soil or substrate B1 was used as cover layer. The soil, substrate B1 and laterite were passed through a $4.0 \mathrm{~mm}$ sieve. The chemical and physical characterization of soil and substrates used in this experiment are shown in tables 2 and 3.

The lysimeters were leached with deionized water every month, approximately for two years, corresponding to 24 leachings. The lysimeters corresponding to the treatments two and six were prepared two months later than the other lysimeters and therefore evaluated in only 22 leachings.

Water was applied at the top and the leachates were collected at the bottom of the lysimeters. In the first month, the amount of applied water was sufficient to obtain $2 \mathrm{~L}$ of leachate, promoting a pre-washing of the material. The amounts applied corresponded to twice the average monthly rainfall 
Table 2. Chemical characterization of soil and substrates used in the experiment

\begin{tabular}{|c|c|c|c|c|c|c|c|c|}
\hline Sample & $\mathrm{pH} \mathrm{H}_{2} \mathrm{O}$ & $\mathbf{P}^{(1)}$ & $\mathbf{K}^{(1)}$ & $\mathbf{C a}^{2+(2)}$ & $\mathrm{Mg}^{2+(2)}$ & $\mathrm{Al}^{3+(2)}$ & $\mathbf{H}+\mathbf{A l}^{(3)}$ & $\mathrm{OM}^{(4)}$ \\
\hline & & \multicolumn{2}{|c|}{$\mathrm{mg} \mathrm{dm}^{-3}$} & \multicolumn{4}{|c|}{$\longrightarrow \operatorname{cmol}_{\mathrm{c}} \mathrm{dm}^{-3} \longrightarrow$} & dag $\mathrm{kg}^{-1}$ \\
\hline Soil & 4.72 & 1.8 & 25 & 0.37 & 0.60 & 1.20 & 3.30 & 0.92 \\
\hline B1 & 4.18 & 4.6 & 9 & 0.07 & 0.06 & 0.24 & 0.40 & 0.00 \\
\hline B2 & 4.04 & 56.6 & 1 & 0.08 & 0.68 & 9.60 & 12.28 & 0.00 \\
\hline
\end{tabular}

(1) Extractor Mehlich 1. ${ }^{(2)}$ Extractor $\mathrm{KCl} 1 \mathrm{~mol} \mathrm{~L}^{-1} \cdot{ }^{(3)}$ Extracted with Ca acetate $1 \mathrm{~mol} \mathrm{~L}^{-1}$ at $\mathrm{pH}$ 7. ${ }^{(4)}$ Organic matter. Soil: B Horizon of Latosol; B1: weathered substrate; B2: little weathered substrate.

Table 3. Physical characterization of soil and substrates used in the experiment

\begin{tabular}{|c|c|c|c|c|c|c|}
\hline Sample & Coarse sand & Fine sand & Silt & Clay & Bulk density ${ }^{(1)}$ & Equivalent moisture ${ }^{(1)}$ \\
\hline & & + & & - & $\mathrm{g} \mathrm{cm}^{-3}$ & $\%$ \\
\hline Soil & 1 & 2 & 38 & 59 & 1.18 & 37.95 \\
\hline B1 & 18 & 7 & 73 & 2 & - & 20.75 \\
\hline $\mathrm{B} 2$ & 51 & 11 & 37 & 1 & - & 18.25 \\
\hline
\end{tabular}

(1) Embrapa (1997). Soil: B Horizon of Latosol; B1: weathered substrate; B2: little weathered substrate.

in the region of Paracatu, calculated from the climatological normal data. This amount of water was applied in the first 20 days of the respective month, and in the remaining days, the lysimeters were left to drain completely, allowing new leaching in the following month.

The leachates were collected monthly, homogenized, and aliquots were sampled to determine $\mathrm{pH}$ and $\mathrm{As}, \mathrm{Fe}$ and $\mathrm{S}$ concentrations, by ICP-OES (wave-lengths of 193.696, 259.939 and $181.975 \mathrm{~nm}$, respectively). Sodium and K concentrations were also determined by flame emission.

At the end of the experiment, the lysimeters were opened and samples collected from the top $(20 \mathrm{~cm})$ of substrate B2 from the treatments 1, 3, 8, and 9 . These samples of the yellowish coatings precipitated on the surface of the coarse B2 material were scraped off. The coatings were ground in an agate mortar, dried at $60^{\circ} \mathrm{C}$, and placed in a separating funnel with bromoform for the concentration of dense minerals (d > 2.81), such as jarosite, natrojarosita, pyrite and arsenopyrite. These concentrated samples were then subjected to mineralogical characterization by X-Ray Diffraction (XRD) and Mössbauer spectroscopy. XRD was performed from 4 to $70^{\circ} 2 \theta$, using a Co source and a graphite monochromator, at $3^{\circ} 2 \theta / \mathrm{min}$ scan. Mössbauer measurements were performed at $298 \mathrm{~K}$ using a standard transmission technique with a source of $57 \mathrm{Co}$ in Rh.

The contents of As, Fe, S, Na, K and acidity $\left(\mathrm{H}^{+}\right)$in the leachates were accumulated over the 24 months. Acidity $\left(\mathrm{H}^{+}\right)$was calculated from the $\mathrm{pH}$ data.

The variances of the homogeneous results were tested, and the analysis of variance was performed evaluating the effects of treatments by orthogonal and additional contrasts, according to Alvarez V. $\&$ Alvarez (2006). The main treatment effects are listed in table 4.

Table 4. Main effects of contrasts

\begin{tabular}{cll}
\hline Contrast & \multicolumn{1}{c}{ Confrontation } & \multicolumn{1}{c}{ Main effect } \\
\hline $\mathrm{C}_{1}$ & B2 without layers vs B2 with layers & Treatments \\
$\mathrm{C}_{2}$ & Soil vs B1 and Soil + B1 in cover layer & Cover layer \\
$\mathrm{C}_{3}$ & B1 vs Soil + B1 in cover layer & Cover layer \\
$\mathrm{C}_{4}$ & Without capillarity break layer vs With capillarity break layer, with soil in & Capillarity break layer \\
\hline
\end{tabular}


Table 4. Continuation

\begin{tabular}{cll}
\hline Contrast & \multicolumn{1}{c}{ Confrontation } & \multicolumn{1}{c}{ Main effect } \\
\hline $\mathrm{C}_{5}$ & With GB vs Without GB and Soil vs B1 in sealant layer, with soil in cover layer & Geochemical barrier and sealant layer \\
$\mathrm{C}_{6}$ & Without capillarity break layer vs With capillarity break layer, with B1 & Capillarity break layer \\
$\mathrm{C}_{7}$ & Soil vs B1 in sealant layer, with B1 in cover layer & Sealant layer \\
$\mathrm{C}_{8}$ & Without GB vs With GB, with B1 in cover and sealant layer & Geochemical barrier \\
$\mathrm{C}_{9}$ & Sand without SO vs Sand with SO in capillarity break layer, with B1 in cover & Sand with sodium oxalate \\
$\mathrm{C}_{10}$ & layer & Sealant layer \\
$\mathrm{C}_{11}$ & Limestone vs Sand with SO in capillarity break layer, with laterite in sealant & Capillarity break layer \\
$\mathrm{C}_{12}$ & Limestone vs Sand with SO in capillarity break layer, with B1 in sealant layer & Capillarity break layer \\
$\mathrm{C}_{\mathrm{A} 1}$ & Without GB vs With GB, with B1 in cover layer & Geochemical barrier \\
$\mathrm{C}_{\mathrm{A} 2}$ & Without sand vs With sand in capillarity break layer & Capillarity break layer \\
$\mathrm{C}_{\mathrm{A} 3}$ & Soil vs B1 in cover layer & Cover layer \\
$\mathrm{C}_{\mathrm{A} 4}$ & Laterite vs B1 in sealant layer & Sealant layer \\
\hline
\end{tabular}

\section{RESULTS}

\section{General treatment effects}

The highest As, Fe and S leaching occured in treatments without capillary break layer. The average leached $\mathrm{As}, \mathrm{Fe}$ and $\mathrm{S}$ amounts were, respectively, $12.36,114.71$ and $214.61 \mathrm{~g} / \mathrm{lysimeter}$, for treatment 2 and 13.96, 111.38 and $220.79 \mathrm{~g} /$ lysimeter for treatment 6 . On the other hand, lower As, Fe and $\mathrm{S}$ amounts were leached from treatments with the presence of GB, in this case. The average leached amounts of $\mathrm{As}, \mathrm{Fe}$ and $\mathrm{S}$ were, respectively, 5.06, 43.30 and $122.44 \mathrm{~g} / \mathrm{lysimeter}$ for treatment 3; $5.71,52.16$ and $138.99 \mathrm{~g} / \mathrm{lysimeter}$ for treatment 8 and 5.64, 50.32 and $137.23 \mathrm{~g} / \mathrm{lysimeter}$ for treatment 9. In these treatments where GB was induced, the $\mathrm{Na}$ and $\mathrm{K}$ concentrations in the leachates were also higher.

There was no significant difference between the control (T1) and the other treatments in the total leached amounts of As, Fe and S. Nevertheless, the acidity and total volume leached were significantly higher in the control than in the other treatments. The opposite was verified for the $\mathrm{Na}$ and $\mathrm{K}$ total contents (Table 5).

In a comparison of the treatments 7 and 8 (Contrast $\mathrm{C}_{\mathrm{A} 1}$ ), it was observed that the geochemical barrier significantly decreased the $\mathrm{Fe}$ and $\mathrm{S}$ leaching, but did not significantly decrease As leaching. On the other hand, when combined with other treatments, GB was efficient to significantly decrease As leaching (contrasts $\mathrm{C}_{5}$ and $\mathrm{C}_{8}$ ).

The acidity production in leachates was high, with average of $14.57 \mathrm{mmol} \mathrm{kg}^{-1}$. This result corresponds to $\mathrm{pH} 2.8$ in leachates. The treatments had little effect on the acidity production.

It was not possible to identify the best material to compose the cover layer. Anyway, the main purpose of the cover is the establishment of vegetation, rather than the decrease of As mobilization (Mello et al., 2003). Therefore, the use of soil in this layer seems to be the best alternative.

The use of soil as sealant layer in this work also seemed to be the best alternative, and the contents of $\mathrm{As}, \mathrm{Fe}$ and $\mathrm{S}$ in the leachate were significantly lower compared to the use of other materials (contrast $\mathrm{C}_{7}$; Table 5). This is probably because the principal secondary As-rich phases were Fe(III)oxyhydroxides (i.e., goethite) (Kocourková et al., 2011). Arsenic and S leaching was significantly lower when laterite was present in this layer, compared to the presence of $\mathrm{B} 1$ substrate, however there was no significant difference to Fe leaching (contrast $\mathrm{C}_{\mathrm{A} 4}$ ).

The presence of a capillary break layer seemed to be important to control As, Fe and S mobility, because the leaching of these elements was significantly higher without it, indicating the significance of the contrasts $\mathrm{C}_{4}$ and $\mathrm{C}_{6}$. Furthermore, the use of limestone significantly decreased (contrast $\mathrm{C}_{12}$ ) the leaching of these elements compared to the use of sand (Table 5).

\section{Mineralogical analyses}

Despite attempts to concentrate samples from the treatments with a geochemical barrier (3, 8 and 9) for mineralogical analysis, the separation of dense minerals with bromoform was not very efficient. The diffraction peaks with higher intensities 
Table 5. Contrasts and their significance for the amounts of As, Fe, $\mathrm{S}, \mathrm{Na}, \mathrm{K}$ and $\mathrm{H}^{+}$and total volume leached from lysimeters (VT), after 24 monthly leachings

\begin{tabular}{|c|c|c|c|c|c|c|c|}
\hline \multirow{2}{*}{ Contrast } & \multicolumn{7}{|c|}{ Contrast } \\
\hline & As & $\mathbf{F e}$ & $\mathbf{S}$ & $\mathrm{Na}$ & $\mathbf{K}$ & $\mathrm{H}^{+}$ & VT \\
\hline & \multicolumn{3}{|c|}{ g/lysimeter } & \multicolumn{2}{|c|}{ mg/lysimeter } & $\mathrm{mmol} /$ lysimeter & L/lysimeter \\
\hline $\mathrm{C}_{1}$ & 0.12 & -4.60 & 1.91 & $1775.91^{* *}$ & $680.84^{* *}$ & $-95.76^{* *}$ & $-9.83^{* *}$ \\
\hline $\mathrm{C}_{2}$ & -0.71 & $-4.72^{\circ}$ & $-6.82^{*}$ & $-405.85^{* *}$ & $211.68^{* *}$ & -15.25 & -0.59 \\
\hline $\mathrm{C}_{3}$ & -0.04 & $6.37^{*}$ & -0.57 & $-3020.63^{* *}$ & $-802.19^{* *}$ & $-54.99 * *$ & -0.90 \\
\hline $\mathrm{C}_{4}$ & $-5.14^{* *}$ & $-47.37 * *$ & $-66.49^{* *}$ & $3863.01^{* *}$ & $778.12^{* *}$ & -23.88 & 1.46 \\
\hline $\mathrm{C}_{5}$ & $4.33^{* *}$ & $48.08^{* *}$ & $51.35^{* *}$ & $-6771.27^{* *}$ & $-1181.79^{* *}$ & 15.70 & 2.74 \\
\hline $\mathrm{C}_{6}$ & $-5.20 * *$ & $-38.28^{* *}$ & $-51.13^{* *}$ & $5271.18^{* *}$ & $1557.53^{* *}$ & -25.94 & -0.54 \\
\hline $\mathrm{C}_{7}$ & $5.18^{* *}$ & $25.67 * *$ & $52.79 * *$ & -224.51 & -198.71 & 19.56 & -0.30 \\
\hline $\mathrm{C}_{8}$ & $-1.49^{\circ}$ & $-27.09^{* *}$ & $-15.47 * *$ & $7536.97^{* *}$ & $1971.67^{* *}$ & -24.64 & $-3.98^{\circ}$ \\
\hline $\mathrm{C}_{9}$ & -0.07 & -1.84 & -1.75 & $591.07^{*}$ & $-525.24^{* *}$ & 7.32 & -3.08 \\
\hline $\mathrm{C}_{10}$ & -0.07 & -0.35 & $-8.39^{\circ}$ & 10.47 & -7.71 & 15.83 & -1.63 \\
\hline $\mathrm{C}_{11}$ & 0.50 & -1.98 & -3.21 & 205.80 & 48.25 & 11.81 & -0.64 \\
\hline $\mathrm{C}_{12}$ & $2.15^{*}$ & $11.88^{\circ}$ & $15.54^{*}$ & 265.41 & 133.27 & $49.29^{\circ}$ & -3.61 \\
\hline $\mathrm{C}_{\mathrm{A} 1}$ & -1.46 & $-26.17^{* *}$ & $-14.60^{*}$ & $7241.43^{* *}$ & $2234.28^{* *}$ & -28.29 & -2.44 \\
\hline $\mathrm{C}_{\mathrm{A} 2}$ & $-6.80^{* *}$ & $-33.05^{* *}$ & $-67.21^{* *}$ & 358.79 & $342.44^{*}$ & -19.29 & 2.26 \\
\hline $\mathrm{C}_{\mathrm{A} 3}$ & $-3.58^{* *}$ & $-29.00^{* *}$ & $-46.61^{* *}$ & $461.54^{\circ}$ & $251.80^{\circ}$ & -0.95 & 1.25 \\
\hline $\mathrm{C}_{\mathrm{A} 4}$ & -0.89 & -7.28 & $-17.77^{* *}$ & -19.34 & -50.22 & -2.90 & -0.15 \\
\hline CV (\%) & 13.04 & 8.96 & 4.56 & 11.20 & 23.83 & 6.97 & 1.69 \\
\hline
\end{tabular}

$\circ,{ }^{*}, * *$ : Significant at 10, 5 and $1 \%$, respectively, by the $\mathrm{F}$ test. $\mathrm{C}_{1}(\mathrm{~T} 1 \mathrm{vs} \mathrm{T} 2+\mathrm{T} 3+\mathrm{T} 4+\mathrm{T} 5+\mathrm{T} 6+\mathrm{T} 7+\mathrm{T} 8+\mathrm{T} 9+\mathrm{T} 10+\mathrm{T} 11+\mathrm{T} 12+\mathrm{T} 13) ; \mathrm{C}_{2}$ (T2+T3+T4 vs T5+T6+T7+T8+T9+T10+T11+T12+T13); $\mathrm{C}_{3}(\mathrm{~T} 5+\mathrm{T} 6+\mathrm{T} 7+\mathrm{T} 8+\mathrm{T} 9$ vs $\mathrm{T} 10+\mathrm{T} 11+\mathrm{T} 12+\mathrm{T} 13) ; \mathrm{C}_{4}$ (T2 vs $\left.\mathrm{T} 3+\mathrm{T} 4\right) ; \mathrm{C}_{5}$ (T3 vs T4); $\mathrm{C}_{6}$ (T5+T6 vs T7+T8+T9); $\mathrm{C}_{7}$ (T5 vs T6); $\mathrm{C}_{8}$ (T7 vs T8+T9); $\mathrm{C}_{9}$ (T8 vs T9); $\mathrm{C}_{10}$ (T10+T11 vs T12+T3); $\mathrm{C}_{11}$ (T10 vs T11); $\mathrm{C}_{12}$ (T12 vs $\mathrm{T} 13) ; \mathrm{C}_{\mathrm{A} 1}$ (T7 vs T8); $\mathrm{C}_{\mathrm{A} 2}$ (T6 vs $\left.\mathrm{T} 7\right) ; \mathrm{C}_{\mathrm{A} 3}$ (T2 vs $\left.\mathrm{T} 5\right)$ and $\mathrm{C}_{\mathrm{A} 4}$ (T10 vs $\mathrm{T} 12$ ).
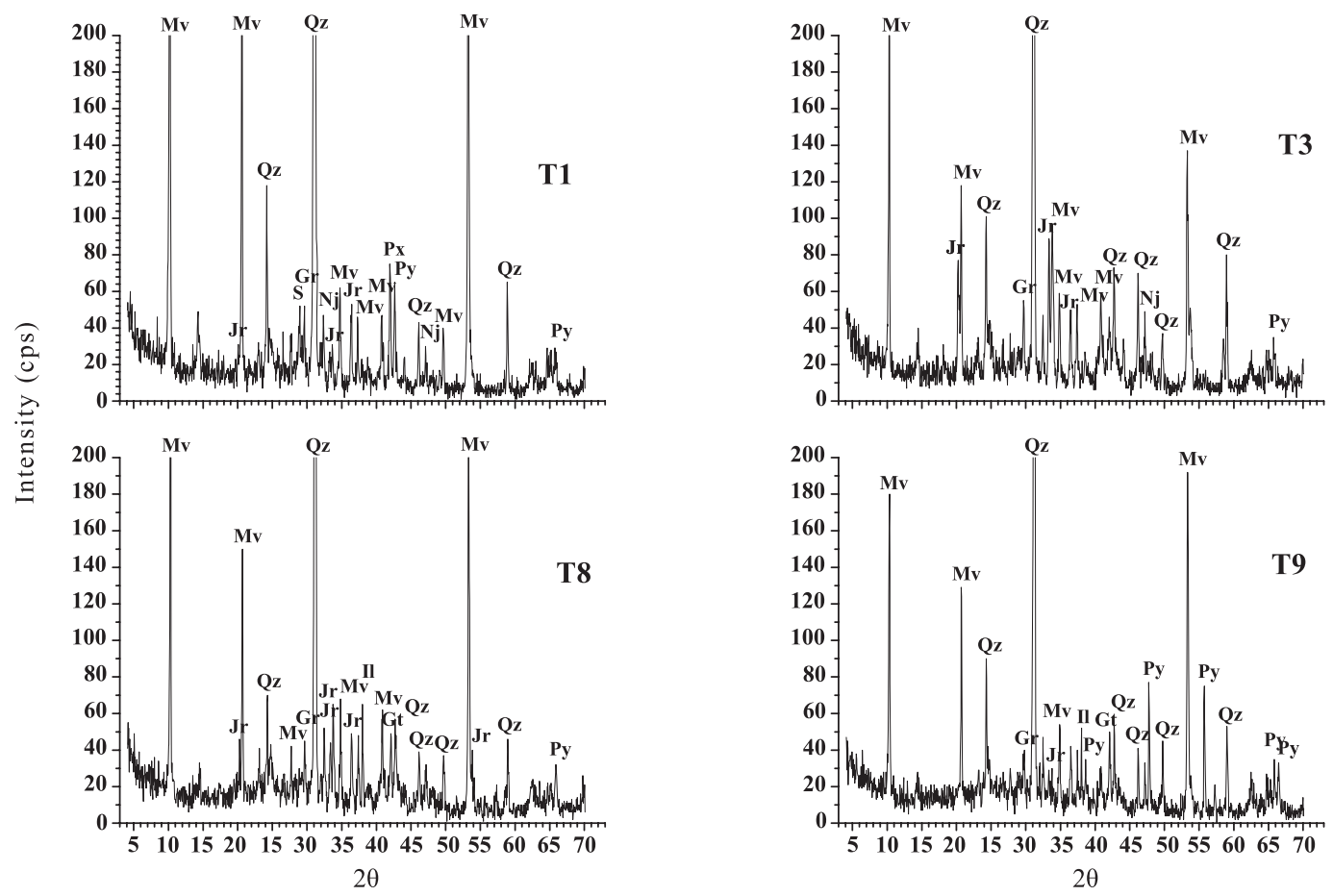

Figure 1.X Ray diffractogram of the samples corresponding to treatments 1, 3, 8, and 9. KaCo Radiation. Qz: Quartz; Mv: Muscovite; Jr: Jarosite; Nt:Natrojarosite; Py: Pyrite; Gr: Greigite; Il: Ilmenite; Gt: Goethite; S: Sulfur; Px: Pyroxene. 
corresponded to quartz and muscovite (Figure 1). No diffraction peaks with intensity higher than $10 \%$ were identified for minerals such as pyrite and arsenopyrite, indicating low concentrations of these sulfides. The same was true for jarosite and natrojarosite.

In the samples corresponding to the treatments 3,8 and 9 it was possible to identify low intensity diffraction peaks for jarosite, and in the control sample (treatment 1) it was possible to identify peaks for jarosite and surprisingly, for natrojarosita. These results indicate that $\mathrm{K}$ addition was efficient to induce jarosite formation and consequently a geochemical barrier, while the addition of $\mathrm{Na}$ was not efficient to induce natrojarosite formation. Low intensities of the diffraction peaks indicate that these minerals are present in low concentrations and probably low crystallinity, as is to be expected for recently precipitated phases, hampering the XRD detection.

The presence of pyrite and jarosite in the samples from treatments $1,3,8$, and 9 was confirmed by Mössbauer spectroscopy. Arsenopyrite has been identified in the B2 substrate by another author (Ribeiro Jr., 2002), but was not identified even by Mössbauer spectroscopy, indicating very low levels of this mineral in those samples.

Calculating the pyrite/jarosite ratio for the relative areas of the Mössbauer spectra, values of $1.70,0.85,1.2$ and 1.16 were found for treatments $1,3,8$, and 9 , respectively. These ratios indicated a larger amount of jarosite in treatment 3 and a smaller amount in the control.

The percentage decrease in As, Fe and S leaching from each treatment in relation to the control (T1) is shown in figure 2 and allows an overview of the effects of the different treatments on the mobility of these elements. Negative values indicate that the treatment caused an increase in $\mathrm{As}, \mathrm{Fe}$ and $\mathrm{S}$ leaching in relation to the control, rather than a

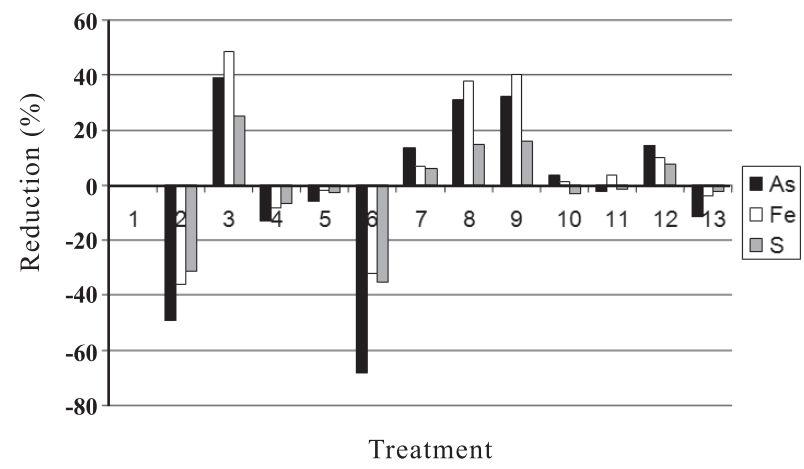

Figure 2. Percentage decrease in arsenic (As), iron $(\mathrm{Fe})$ and sulphur (S) leachate, compared to the control (T1), after 24 monthly leachings. decrease. This occurs in the treatments without sealant layer. There is no moisture gradient between the capillarity break layer and substrate B2, and the sealant layer provides water for an extended period of time, with the increase of oxidation.

However, it is noteworthy that the method, based on natural conditions simulated in lysimeters, has limitations. Thus, the extrapolation of results to field conditions should be treated with caution.

\section{DISCUSSION}

The use of lime alone to raise $\mathrm{pH}$ and precipitate some of the solubilized elements when arsenopyrite is present is not appropriate because the solubility of arsenic soil (V) increases with increasing $\mathrm{pH}$ (Zhang $\&$ Selim, 1998). Thus, the use of a geochemical barrier associated with other treatments such as the use of different combinations of layers on the sulfide substrate is suggested as a promising alternative. This technique was tested under controlled laboratory conditions, using lysimeters. Field studies are needed to prove the efficacy of this technique in decreasing the leaching of the elements studied.

It has been shown that jarosite can precipitate as a cover layer on the crystal surfaces, preventing pyrite oxidation (Webb et al., 2003). Therefore, the decrease of As, Fe and $\mathrm{S}$ leaching due to jarosite formation is not necessarily caused by adsorption or co-precipitation phenomena, but can also be ascribed to the encapsulation of sulfide minerals.

The use of $\mathrm{Na}$ oxalate, applied on top of the capillarity break layer, was not effective to reduce the leachate water volume. This product could be applied on the sealant layer, promoting clay dispersion, reducing the permeability of the material. Likewise, the presence of organic acid had no significant effect on the leaching of the studied elements.

Acidity production was significantly higher in the control than in the treatments. The high acidity production in all treatments suggests that they were not affected by the $\mathrm{pH}$ increase in the leachate, and that substrate B2 does not contain sufficient amounts of carbonates to neutralize the acidity generation. These results corroborate the acid-base balance analysis published by Corrêa (2002).

The larger total leachate volume from treatment 1 (control), compared to the average of the other treatments, reflects the higher acidity production. Therefore, the use of cover, sealant and capillary break layers had a positive effect by reducing the leachate amount due to the water retention in the layers above the sulfide substrate, but did not significantly affect the AMD production. 
Although soil use in the sealant layer increased the oxidation rate of the sulfide substrate when the capillarity break layer was absent. The use of substrate B1 in both sealant and cover layers increased $\mathrm{As}, \mathrm{Fe}$, and $\mathrm{S}$ leaching $\left(\right.$ Contrast $\mathrm{C}_{7}$ ). The higher concentrations of these elements in substrate B1 than in the soil were responsible for higher leachates. Consequently, the mobilization of As, $\mathrm{Fe}$ and $\mathrm{S}$ began in the upper layers and this effect surpassed the mobilization arising from sulfide oxidation in substrate B2 when soil was present in the sealant layer. Soil constituents in the sealant layer could have retained part of $\mathrm{As}, \mathrm{Fe}$ and $\mathrm{S}$ mobilized from substrate B1 in the cover layer. It can be considered that not only the characteristics of the materials of the sealant, cover or capillary break layers, but also the water dynamics in the systems were important to define element mobilization.

Leaching of As, Fe and S was lower when limestone was used instead of sand as capillary break layer. This can be attributed to the precipitation of $\mathrm{Fe}$ and possibly, $\mathrm{S}$ as iron sulfates on the limestone surface. The $\mathrm{pH}$ increase in this layer possibly allowed arsenic adsorption or co-precipitation by $\mathrm{Fe}$ oxides. In short, the presence of the capillary break layer, regardless of the additional treatments, decreased As, Fe and S leaching.

The detection of jarosite in the control (T1) suggests that the sulfate can occur naturally as a consequence of the sulfide substrate (B2) oxidation, since the $\mathrm{pH}$ of the leachate was less than three; and that $\mathrm{Fe}, \mathrm{S}$ and $\mathrm{K}$ concentrations in solution are sufficient to induce precipitation on the treatment. By the way, the precipitation is possibly only accelerated by the addition of $\mathrm{Na}$ and $\mathrm{K}$ and a further decrease in As, Fe and S mobilization is favored.

\section{CONCLUSIONS}

1. Neoformation of jarosite was found to be a natural process in a sulfide substrate from a gold mine in Brazil subjected to oxidizing conditions in leaching lysimeters for two years. The formation of a geochemical barrier in the substrate accelerated this process, resulting in lower As, Fe and S leaching.

2. Arsenic mobilization was only decreased significantly when $\mathrm{Na}$ and $\mathrm{K}$ addition was combined with other treatments.

3. There were significant differences in the leached amounts of $\mathrm{As}, \mathrm{Fe}$ and $\mathrm{S}$, according to different combinations of materials covering the sulfide substrate.

4. The presence of cover, sealant or capillary break layers was not able to raise the $\mathrm{pH}$ of leaching solutions even when limestone gravel was added, but a capillarity break layer with coarser material seemed to establish a moisture gradient that affected the oxidation dynamics of the sulfide substrate.

\section{ACKNOWLEDGEMENTS}

The authors are indebted to the Foundation for Research Support of Minas Gerais State (FAPEMIG) and National Institute of Science and Technology Mineral Resources, Water and Biodiversity (INCTAqua, $\mathrm{CNPq}$ ) for financial support, and to the National Council for Scientific and Technological Development (CNPq) for a master fellowship.

\section{LITERATURE CITED}

ALPERS, C.N. \& BLOWES, D.W., ed. 'Environmental geochemistry of sulfide oxidation.' Washington, DC, American Chemical Society, 1994. (ACS Symposium Series, 550)

ALVAREZ V., V.H. \& ALVAREZ, G.A.M. Comparação de médias ou teste de hipóteses? Contrastes! B. Inf. SBCS, 31:24-34, 2006 .

AGENCY FOR TOXIC SUBSTANCES \& DISEASE REGISTRAY - ATSDR. CERCLA Priority list of hazardous substances. $<$ http://www.atsdr.cdc.gov/cercla/07list.html > Accessed 28 June 2011.

BIGHAM, J.M.; SCHWERTMANN, U.; TRAINA, S.J.; WINLAND, R.L. \& WOLF, M. Schwertmannite and the chemical modeling of iron in acid sulfate waters. Geochim. Cosmochim. Acta, 60:2111-2121, 1996.

CORRÊA, M.L.T.; MELLO, J.W.V. \& COSTA, L.M. Métodos de análises de sulfetos em amostras de rochas e sedimentos. R. Bras. Ci. Solo, 26:103-115, 2002.

DAVE, J.M. Arsenic contamination of drinking water in Bangladesh. World Health Organization Project. BAN CWS 00, 1996. p.3-5.

DESISTO, S.L.; JAMIESON, H.E. \& PARSONS, M.B. Influence of hardpan layers on arsenic mobility in historical gold mine tailings. Appl. Geochem., 26:2004-2018, 2011.

EMBRAPA - Centro Nacional de Pesquisa de Solos. Manual de métodos de análise de solo / Centro Nacional de Pesquisa de Solos. $2^{\text {a }}$ edição. Rio de Janeiro, 212p, 1997.

EVANGELOU, V.P. Pyrite oxidation and its control. Boca Raton, CRC PRES, 1995. 293p.

FANNING, D.S. \& FANNING, M.C.B. Soil: Morphology, genesis, and classification. New York, John Wiley \& Sons, 1989. 395p.

GAGLIANO, W.B.; BRILL, M.R.; BIGHAM, J.M.; JONES, F.S. \& TRAINA, S.J. Chemistry and mineralogy of ochreous sediments in a constructed mine drainage wetland. Geochim. Cosmochim. Acta, 68:2119-2128, 2004. 
HUANG, R.Q.; GAO, S.F.; WANG, W.L.; STAUNTON, S. \& WANG, G. Soil arsenic availability and the transfer of soil arsenic to crops in suburban areas in Fujian Province, southeast China. Sci. Total Environ., 368:531-541, 2006.

JAMBOR, J.L.; BLOWES, D.W. \& RITCHIE, A.I.M., eds. 'Environmental aspects of mine wastes'. Ottawa, Mineralogical Association of Canada, 2003.

KOCOURKOVÁ, E.; SRACEK, O.; HOUZAR, S.; CEMPÍREK, J.; LOSOS, Z.; FILIP, J. \& HRŠELOVÁ, P. Geochemical and mineralogical control of the mobility of arsenic in a waste rock pile at Dlouhá Ves, Czech Republic. J. Geochem. Explor., 110:61-73, 2011.

MELLO, J.W.V.; DIAS, L.E. \& CORREA, M.L.T. Drenagem ácida: Avaliação do potencial de ocorrência, mitigação e revegetação de substratos sulfetados. In: CURI, N.; MARQUES, J.J.; GUILHERME, L.R.G.; LIMA, J.M.; LOPES, A.S. \& ALVAREZ V., V.H. eds., Tópicos em Ciência do Solo. Viçosa, MG, Sociedade Brasileira de Ciência do Solo, 2003. v.3. p.401-430.

MURAD, E. \& ROJÍK, P. Jarosite, schwertmannite, goethite, ferrihydrite and lepidocrocite: The legacy of coal and sulfide ore mining. Australian New Zealand Soils Conference. Sydney, University of Sydney, 2004.

RIBEIRO JR, E.S. Adsorção e dessorção de arsênio em solos e substratos de mineração de ouro e práticas de mitigação de drenagem ácida em lisímetros de lixiviação. Viçosa, MG, Universidade Federal de Viçosa, 2002. 102p. (Tese de Doutorado)
ROBINSON, B.C., ed. Mine drainage and related problems. New York, Nova Science Publishers, 2010. 275p. (Environmental Science, Engineering and Technology)

SCHWERTMANN, U. \& CARLSON, L. The pH-dependent transformation of schwertmannite to goethite at $25^{\circ} \mathrm{C}$. Clay Miner., 40:63-66, 2005.

SINGH, B.; WILSON, M.J.; McHARDY, W.J.; FRASER, A.R. \& MERRINGTON, G. Mineralogy and chemistry of ochre sediments from an acid mine drainage near a disused mine in Cornwall, U.K. Clay Miner., 34:301-317, 1999.

WEBB, C.J.; DAVIS, A.D.; DIXON, D.J.; WILLIAMSON, T.E.; SORENSEN, J.; FIVECOATE, R.; DAWADI, S. \& BERRYMAN, G.E. An investigation of the formation of arsenic-containing minerals on a limestone base. Presented at Geological Society of America, Annual Meeting. Abstracts with Programs...Denver, 2003. p.566.

ZHANG, H. \& SELIM, H.M. Reaction and transport of arsenic in soils: Equilibrium and kinetic modeling. Baton Rouge, Louisiana State University, 1998. (Advances in Agronomy, 98) 
